https://doi.org/10.1590/198053146035

\title{
LISTENING TO THE CHILDREN IN RESEARCH AND QUALITY OF EARLY CHILDHOOD EDUCATION
}

\author{
Silvia Helena Vieira Cruz' \\ Sandra Maria de Oliveira Schramm" \\ TRANSLATED BY Erika Kirsten Dobe
}

\begin{abstract}
Based on the image that Childhood Pedagogy has been creating of children as rich, competent, diverse, and with rights, the article highlights their perspective on themes related to their educational experiences. Based on research studies done in Brazil, published between 2008 and 2018, which heard children, this paper presents voices expressing opinions, wishes, complaints, and fears about subjects such as discipline, play, ethnic-racial relations, and the transition to elementary school. These voices express the competence of children to evaluate the educational services meant for them and often reveal violations of rights that are guaranteed in official documents. These voices need to be heard and considered to build the quality of early childhood education.
\end{abstract}

CHILDREN • PARTICIPATION • EDUCATIONAL QUALITY • EARLY CHILDHOOD EDUCATION

\section{ESCUTA DA CRIANÇA EM PESQUISA E QUALIDADE DA EDUCAÇÃO INFANTIL}

\section{Resumo}

A partir da imagem que a Pedagogia da Infância vem construindo das crianças como ricas, competentes, diversas e com direitos, o artigo destaca as perspectivas acerca de experiências educativas. Com base em pesquisas que ouviram crianças e que foram realizadas no Brasil e publicadas entre 2008 e 2018, são trazidas vozes que expressam opiniões, desejos, reclamações, temores sobre temas como disciplina, brincadeiras, relações étnico-raciais e transição para o ensino fundamental. Essas vozes expressam a competência das crianças em avaliar os serviços educativos destinados a elas, e muitas falam de violações de direitos assegurados em documentos oficiais.

CRIANÇAS • PARTICIPAÇÃO • QUALIDADE DA EDUCAÇÃO • EDUCAÇÃO INFANTIL

I Universidade Federal do Ceará (UFC), Fortaleza (CE), Brazil; https://orcid.org/0000-0002-3406-3005 ; silviavc@uol.com.br

II Universidade Estadual do Ceará (UECE), Fortaleza (CE), Brazil; https://orcid.org/0000-0002-3631-7638; sandra.schramm@uece.br

III Universidade Federal do Ceará (UFC), Fortaleza (CE), Brazil; https://orcid.org/0000-0002-0875-7230; ikabella2000@yahoo.com 


\section{ÉCOUTE DES ENFANTS DANS LA RECHERCHE ET QUALITÉ DE L'ÉDUCATION}

\section{Résumé}

À partir de l'image crée par la pédagogie de l'enfance considérant les enfants comme des êtres riches, compétents, divers et détenteurs de droits, cet article met en avant les perspectives au sujet de certaines expériences éducatives. Sur la base de recherches menées au Brésil et publiées entre 2008 et 2018 concernant l'écoute des enfants, des voix se font entendre qui expriment des opinions, des désirs, des plaintes et des craintes sur des thèmes tels que la discipline, les jeux, les relations ethniques et raciales et le passage de l'école maternelle à l'école fondamentale. Elles affirment que les enfants ont la capacité d'évaluer les services éducatifs qui leur sont destinés et que beaucoup parmi eux évoquent les violations des droits garantis par les documents officiels.

ENFANTS • PARTICIPATION • QUALITÉ DE L'ÉDUCATION • EDUCATION DE LA PETITE ENFANCE

\section{ESCUCHAR A LOS NIÑOS EN LA INVESTIGACIÓN Y CALIDAD DE LA EDUCACIÓN INFANTIL}

\section{Resumen}

A partir de la imagen que la Pedagogía de la Infancia está construyendo de los niños como si fueran ricos, capaces, diversos y con derechos, el articulo enfatiza sus perspectivas acerca de los temas relativos a sus experiencias educativas. Con base en investigaciones hechas en Brasil, publicadas entre 2008 y 2018, que han escuchado a los niños, hemos traídos voces que expresan opiniones, deseos, quejas, miedos sobre temas como disciplina, bromas, relaciones étnico-raciales y transición hacia la educación básica. Esas voces expresan la capacidad de los niños para evaluar los servicios educativos destinados a ellos y muchas veces revelan violaciones de derechos que les son asegurados en documentos oficiales. Son voces que necesitan ser oídas y consideradas en la construcción de la calidad de la educación infantil.

\section{NIÑOS • PARTICIPACIÓN • CALIDAD DE LA EDUCACIÓN • EDUCACIÓN INFANTIL}




\section{INTRODUCTION: PEDAGOGY AND EDUCATING THE CHILD}

The main objective of educating the child and young adult is to mold them to norms, promote their socialization, in the meaning formulated by Durkheim in the first decades of the 20th century. It is be up to Pedagogy to contribute to the civilization of adults and of society. Hence, its greatest reference has not been childhood, but the civilized adult. Not that Pedagogy ignores the peculiarities of children, but its action, in general, aims to adapt them to what is considered acceptable.

To accomplish this mission, Pedagogy makes use of knowledge produced by the sciences, particularly Philosophy and Psychology. Already in the mid-19th century, Herbart proposed that from Philosophy one should take the purposes of education and from Psychology the path, the means, and the obstacles (WARDE, 1997).

The idea of childhood is connected to fundamental philosophical themes of pedagogical thought. For Charlot (1983, p. 113, own translation), "in Plato, as in all the great classic pedagogical systems, the theory of childhood fits together with a theory of human nature and of culture" 1 . And it is important to emphasize that both for Traditional Pedagogy and for New Pedagogy, the child is dealt with in terms of nature. In the tradition assumed by the former, a bad nature, 
already originally corrupted (wherein lies the need for the child to be tamed); in the innovative perspective initiated by Rousseau (1999), a good nature, but subject to corruption (thus, there is a need to protect it). In both, the social and economic significance of childhood and the social inequalities among children are reduced ideologically to an issue of human nature, in which they coincide, despite everything.

From the start, a strong current was under construction in Psychology. Understanding it as the science of behavior, it was based on values such as measurement, classification, standardization, prediction. Thus, working with certain investigative practices, it studied the characteristics of "the child", that is, allegedly universal.

As Warde (1997) pointed out, Claparède already insisted, in 1940, that Pedagogy be based on knowledge "of the child". And it was basically by this Psychology that Pedagogy allowed itself to be seduced: it appropriated Psychometrics and Experimental Psychology in order to consider itself "scientific" (CARVALHO, 1997; FREITAS, 2002).

However, in the initial decades of the 20th century, Vigotski and Wallon constructed knowledge of children's development by situating them in specific sociocultural environments and expanding the focus to beyond the observable behavior; the research dealt with individual children, though marked by the interactions they establish. It is easy to note, however, that this perspective has not been incorporated by the pedagogical models based on a transmissive conception $^{2}$ of education and on a prejudiced view of poor children.

At present, there is an awareness that "childhood, as a social construction, is always contextualized in relation to time, to place and culture, and varies according to class, gender and other socioeconomic conditions"3 (DAHLBERG; MOSS; PENCE, 2003, p. 71, own translation). However, the transmissive pedagogies, still predominant, consider childhood in terms of a universal abstraction; they do not value the generational and sociocultural singularities of the children. They see, therefore, the diverse as being inferior and blame the children and their families for not meeting expectations, ignoring conditions (environmental, curricular, relational, social, etc.) involved in learning processes.

\section{THE IMAGE OF THE CHILD AND EARLY CHILDHOOD EDUCATION}

This first initiatives offering service to the poor child in our country were part of the so-called scientific assistance, which counted among its functions the role of disciplining the poor and the working class and promoting social control. One

2 In traditional transmissive education the objective is transmission, by the teacher, of a set of information (considered important by society) to the child, taken as a "blank slate" that should memorize and reproduce this content (OLIVEIRAFORMOSINHO; FORMOSINHO, 2O11).

3 In the original: "a infância, como construção social, é sempre contextualizada em relação ao tempo, ao local e à cultura, variando segundo a classe, o gênero e outras condições socioeconômicas". 
of the objectives of these initiatives was to avoid criminality of the "helpless childhood" (KUHLMANN JR., 1998).

Meanwhile, the institutions aimed at children belonging to medium and upper layers showed concerns with child development and knowledge acquisition. One of the great concerns was preparing children for elementary education.

To some degree, many daycares and preschools are heirs of this past even today. As indicated in several works (for example, ANDRADE, 2007; CAMPOS; FÜLLGRAF; WIGGERS, 2006; CRUZ, 2002; MARTINS, 2009; and SCHRAMM, 2009), children are not seen in their needs and desires that are peculiar to and present in different age groups; disciplining is an obstacle to building the autonomy and identity of children; children's education is not aimed at the moment they live, but at an undesirable future (centered on discipline) or, more recently, focuses on what is considered desirable for the child's school trajectory (leading, recurrently, to precocious schooling). At any rate, the "clientele" to which education is destined largely defines its quality.

It should be highlighted as well that the many stereotypes and prejudices present in society about poor children (as with others, especially those related to people of color) also mark the relationships established with children and their families (OLIVEIRA, 2004; CAVALLEIRO, 1998; DIAS, 2007; ROSEMBERG, 1996; SILVA, 2002, among others). These stereotypes and prejudices complicate a true approximation with the real children who attend daycares and preschools.

Already in the 1920s, Korczak (1986, p. 72-75, own translation), denounced several negative ideas that adults have about children:

[...] he does not know, guess, sense. [...] Weak, small, poor, dependent [...] A brat, a kid, a man in the future, but not today. But will be. [...] Gladly listens to evil whisperings, follows the worst examples [...] Nothing is his due, we give of our own goodwill. ${ }^{4}$

Therefore, in consequence, using the words of the same author, "we dismiss a child" and "childish doubts and reservations seem to be of little importance". We should "combat whim, fancy, and obstinacy", "maintain a vigil, deny independence"; in sum, "we must instruct, guide, break in, slow down, suppress, straighten out, warn, prevent, impose and combat" (KORCZAK, 1986, p. 72-75, own translation).

4 In the original: "ela nada sabe, nada adivinha, nada pressente. [...] [É] Fraca, pequena, pobre, dependente [...] Um fedelho, apenas uma criança, um futuro homem, um quase nada no presente, só um dia existirá de verdade. [...] Parece estranhamente atraída pelo mal, tende a dar ouvido aos conselhos perversos [...] Ela não tem direitos, o que ganha é fruto da nossa boa vontade."

5 In the original: "menosprezamos a criança" and "as dúvidas e incertezas infantis nos parecem tão desprovidas de seriedade". [...] "combater suas manhas, caprichos e obstinações", [...] "vigilantes, nada de iniciativas próprias" [...] "instruí-la, guiá-la, governá-la, reprimi-la, refreá-la, corrigi-la, alertá-la, protegê-la dos perigos, impor-lhe os valores certos, impedi-la de adotar os errados". 
It might seem like this view of children, marked by what we could call generational prejudice, is being presented in an overly negative form, but, in truth, it is expressed very frequently in a large part of daycares and preschools, where a transmissive traditional education predominates. However, on the countercurrent of this Pedagogy, there has been an effort in recent decades to alter this image of the child and the role she occupies in the daily life of educational institutions.

Having as one of its main references the pedagogical approach constructed in northern Italy, whose great idealizer and coordinator was Loris Malaguzzi, a Childhood Pedagogy or Childhood Education Pedagogy has been in construction in several countries wherein children assume a central role in the pedagogical practice. In this perspective, the children, in collaboration with their peers, participate with liberty, agency, intelligence, and sensibility in their learning and development in all moments of the pedagogical practice, from planning to reflecting on what is being done or what was done. Largely, this arises from the image held of children: rich, competent, diverse, and with rights.

This image, together with a corresponding positive idea of the teacher and the families, supports the development of a pedagogy in which the child is heard. Indeed, the relationships and interactions between people (children and adults) constitute the central means of attaining a participative pedagogy (OLIVEIRA-FORMOSINHO; FORMOSINHO, 2011) and it is only by listening that one achieves dialogue, relationships, and interactions. In this manner alone is it possible to develop educational practices that respect children, considering their genuine wishes, needs, skills, curiosities, etc.

Consistent with the centrality of the image of the child in anchoring pedagogical practices, the National Curricular Guidelines for Early Childhood Education (BRASIL, 2009, own translation) state, in Article 4:

\begin{abstract}
The pedagogical proposals of Early Childhood Education must consider that the child, the center of curricular planning, is the historical and rightful subject who, in the interactions, relationships, and daily practices she experiences, constructs a personal and collective identity, plays, imagines, fantasizes, desires, learns, observes, experiments, narrates, questions, and builds senses about nature and society, producing culture. ${ }^{6}$
\end{abstract}

Building an image of children as rich, competent, diverse, and with rights is still a challenge, in a society where disparaging conceptions of these subjects prevail. This construction, however, is absolutely necessary for the development

6 In the original: "As propostas pedagógicas da Educação Infantil deverão considerar que a criança, centro do planejamento curricular, é sujeito histórico e de direitos que, nas interações, relações e práticas cotidianas que vivencia, constrói sua identidade pessoal e coletiva, brinca, imagina, fantasia, deseja, aprende, observa, experimenta, narra, questiona e constrói sentidos sobre a natureza e a sociedade, produzindo cultura." 
of quality education for children, one that provides good conditions for their learning, development, and welfare. We consider that, side by side with other elements, research with children can contribute strongly to this process.

\section{THE QUALITY OF EARLY CHILDHOOD EDUCATION AND RESEARCH WITH CHILDREN}

Contemporary discussions about quality in early childhood education indicate the need for participation of all those involved in the process of defining it. Oliveira-Formosinho (2001) considers that this process must be participative, problematizing, dynamic, and situated. Dahlberg, Moss, and Pence (2003) also cite the importance of the very process of defining quality, a subjective concept, based on values, relative and dynamic; thus the need to contextualize quality spatially and temporally, recognizing cultural diversity and other things. In the same line, Bondioli (2004) defends that there is no quality without participation. Therefore, when imagining quality education for the child, she too must be heard. The child is heard not only in the quotidian of pedagogical practices, as menu6tioned previously, but also through research.

Since the beginning of the 20th century, the nascent Developmental Psychology has sought to understand the child, in her different dimensions and on several topics: thought, language, play, emotions, morals. In what way is she shaped into a person? What is the relationship she establishes with objects, with other people, with culture? What factors preside over the transformations observed? Many questions were formulated, required the elaboration of research strategies, and produced a vast quantity of knowledge about characteristics and processes typical to children (or "the child", in a perspective of finding elements common to all children). Thus, what is innovative and relatively recent is the scientific production that focuses on the children not to assess them or define some of their peculiarities, but to know what they think and feel about subjects that concern them.

Research studies with children consider childhood as a social construction and a variable of social analysis that cannot be divorced from other variables like social class, gender, or ethnic belonging (JAMES: PROUT, $1990^{7}$, apud SARMENTO, 2008). They perceive children as competent to express their opinions, misgivings, desires, etc.; they believe in a specific way that children capture or appropriate information and processes from the adult world, in a process of interpretative reproduction (CORSARO, 2001, 2009); and they are interested in capturing the perspectives of these social actors.

Previous studies conducted with children expand our knowledge on the educational contexts destined to them and our possibilities for improving the quality of education that takes place in daycares and preschools. Furthermore,

7 JAMES, Allison; PROUT, Alan (ed.). Constructing and reconstructing childhood: contemporary issues in the sociological study of childhood. London: The Falmer Press, 1990. 
they reinforce the image of the child as competent to present, firsthand, her perspective on the school experience, thus contributing to the construction of a realer and fairer image of children.

\section{CHILDREN TALK ABOUT DAYCARE AND PRESCHOOL}

The research studies discussed here were conducted and/or published in Brazil, within the last ten years (period from January 2008 to January 2018). Among their objectives was listening to children between zero and five years of age, utilizing some interview strategy or other resource to encourage children to speak, that is, to use verbal expressions. However, this limitation is not intended to disregard the importance of analyzing the more diverse languages of the children and the relevance of perfecting the research strategies that examine them.

These studies were located using the electronic portals of Scientific Electronic Library Online (SciELO), the Biblioteca Digital Brasileira de Teses e Dissertações [Brazilian Digital Library of Theses and Dissertations] (BDTD), the Banco de Teses e Dissertações da CAPES [CAPES Bank of Theses and Dissertations], and Work Group 07 (GT 07 - Educação de Crianças de 0 a 6 anos [Education of Children from 0 to 6 years]) of the Associação Nacional de Pós-Graduação e Pesquisa [National Association of Graduate Studies and Research] (ANPEd). The following keywords were utilized: "research with children", "listening to the child" and "child's perspective" for the identification of these studies. We also considered the recent work of Cruz and Martins (2017), which focuses on what children have to say on topics related to public policies, by means of several studies in which they were heard.

We present here children's words, seeking to organize them according to the main subjects addressed, beginning with their perceptions about the early childhood education institution they attend, including the issue of discipline and imposition of rules as well as the presence of conflicts and physical aggressions. The other subjects addressed are recess, play, the image of the good teacher, the transition to elementary school, and ethnic-racial relations.

Children, between four and six years of age, expressing their perception of experiences in a public education institution located in Fortaleza, Ceará, presented an educational context in which they felt oppressed (CRUZ, 2009). Their speech provided indications that remaining in school did not seem safe, resulting almost always in suffering, as expressed in the words used when saying how they felt at the institution: "alone", "tummy ache", "crying”, "anger", "upset", "tied hands", "caged", "thinks [the school, the teacher, the work] is awful", "locked up". The routine was seen as something tedious and unpleasant, marked by performing assignments and receiving punishments: "every day the work is the same", "it is awful making small letters", and "if we don't do the assignment, the teacher puts us in time-out!"

Another relevant datum from this research was the ascertainment that children could discern what would constitute a good educational context for them: 
in it, "classes" or "assignments" are important, but well balanced with plenty of play activities done in spacious, receptive places and equipped for the realization of free play. One child, for example, stated regarding an imaginary situation: "the girl is at school doing the assignment in the playhouse". The children expressed a strong desitre to learning in a significant and pleasurable place. As it was emphasized by the researcher, "many of the suggestions pinpointed by the children [...] constitute the basic conditions that should exist at any childhood education institution"8 (CRUZ, 2009, p. 17, own translation).

Five-year-olds, heard by Pamphylio (2010) in an educational institution of the rural community of Anauerapucu, in Amapá, also expressed a negative conception of school. They referred to situations that displeased them in the routine at the institution, such as "punishments". This displeasure became more evident when they talked about liking to "drink water" or "the water fountain", which would justify constant exits and opportunity to "wander around the school patio"; thus, the children expressed that the "classroom" was not a pleasant place to be.

One aspect that appears to contribute to these sentiments is the heavy presence and function that discipline takes on in their daily life at school, turning it into a process of disciplining, as Foucault (2005) calls it. The children bring up this theme in several studies.

The objective of one of the studies that addressed this topic (ALMEIDA, 2015), conducted in a public childhood education institution in the city of Estância, in Sergipe, was to capture the ways children participate in school routines. The results showed that the five-year-olds did not comprehend the meanings of the rules established, a consequence of arbitrary impositions in a context marked by disciplining. As in other contexts, there was a clear lack of understanding on the part of teachers and other educators about the children's right to participate socially in routines and to understand what justifies reasonable rules.

Following rules and obeying the teacher are considered awful impositions in the perception of children. The words of one of the children participating in Schramm's (2009) research reveal how this made it difficult, in the role of a child, to exist in a school routine that did not respect their right to be heard and to make choices: "it is bad because you have to obey" (SCHRAMM, 2009, p. 176).

Similarly, five-year-olds from a municipal public institution in Nova Iguaçu, Rio de Janeiro, in presenting their perspectives on the right to education, said that what they did not enjoy in the educational experiences were the disciplinary rules to which they were subjected each time their behavior was considered unacceptable, such as: horsing around, fighting, hitting (TAVARES, 2015). Possibly this displeasure was related to the imposition of rules that seemed senseless, because, as Formosinho and Oliveira-Formosinho (2013) state, understanding rules is a basic condition for children to feel like participants and "belonging"

8 In the original: "muitas das sugestões apontadas pelas crianças [...] constituem as condições básicas que deveriam existir em qualquer instituição de Educação Infantil". 
to a context. Moreover, as the children expressed, this is fundamental to their welfare and disposition to learn and develop.

In addition to the teachers' disciplining practices, the reprimands they receive, and the assignments they must complete, another element that the children dislike in the school daily life is the presence of conflict amongst themselves. The children heard by Corsi (2010) brought an important contribution to understanding how they perceive the conflicts they experience. The research participants, who were between five and six, attended a public education institution in the city of São Paulo. They revealed that, contrary to what adults seem to believe, to them, conflict is not only what physically hurts them or represents a disrespect for rules, but also things that make them sad, frustrated, or afraid.

Children from cities of Brazil, Colombia, and Peru referred frequently to conflicts and physical fights amongst themselves, as well as rudeness and bad language (CAMPAÑA LATINOAMERICANA POR EL DERECHO A LA EDUCACIÓN, 2013). They reported shoves and punches, particularly by boys against girls and bigger against smaller. It is such a pervasive situation that the children listed among the qualities of a good friend the fact that they were strong and could protect them from possible aggressions from other classmates. This indicates the need for an educational project that problematizes and seeks alternatives for this situation, not to mention the evident lack of adult supervision in all spaces of school life.

The presence of conflicts and physical aggressions among children during recess led the children heard by Santos (2015) to denounce the lack or insufficient number of adults in the spaces where this activity took place. The researcher analyzed children's conceptions of recess as a routine activity in a municipal public preschool of Fortaleza and, when asked what they needed to make recess "really great", the children said: "Someone to watch the children". Another important children's claim was the availability of differentiated toys in good conditions. In their conceptions, a good recess needs to have "a slide, scooter, pool, toys, sand toys, sand bucket... Because they are all broken...” Thus, they believe that they need to appeal to prayer: "Ask God for newer toys and a toy hospital ..." (CRUZ; SANTOS, 2016, p. 181).

In this environment, where the prevailing objective of school activities is elementary school preparation, the children said emphatically that recess was the most important activity of the routine, with play and interactions with other children being what they most valued at the institution. They considered recess so relevant that, considering its hypothetical absence, they affirmed that not only would it cause great sadness, but also that "the children would change schools!" (SANTOS, 2015, p. 113). 
In several other studies, the children reaffirmed the central importance that play held for them, ${ }^{9}$ linking it to conceptions of children and childhood. In the study conducted by Martins (2009), for example, five-year-olds at a municipal institution in Fortaleza showed that they appreciated free play (seen as "horsing around" by the teacher) so much that they sought clandestine ways that it could happen in the classroom. The teacher, on the other hand, valued planned and directed play with the purpose of promoting learning, but the children did not identify it as play: “In the room you can't [play]. In the room it is just talking in the circle and doing assignments" (p. 169). Thus, this study expanded knowledge on children's participation in the constitution of play and likewise contributed to a better understanding of how they perceive and sense the place that adults designate for play at the early childhood education institution.

The speech of children heard by Schramm (2009) also revealed how disgusted they felt by the non-satisfaction of their wishes and need to play. Being in an environment where play was very restricted, they desired this possibility. Play was the activity pinpointed by almost every child as something that would make them happy at school. As one girl, explaining a drawing she had produced, said: "It is the teacher letting her [the girl] play every day" (p. 183).

In an educational institution in the rural community of Anauerapucu, Amapá, five-year-olds who participated in the study developed by Pamphylio (2010), linked their conceptions of childhood to the possibilities of play. The relationships with classmates were also present when reflecting on school: in their conceptions of the institution, they seemed to idealize a pleasant space to make friends.

Similarly, when expressing their conceptions about the early childhood school, five-year-olds from Ribeirão Preto, São Paulo, revealed that it is, mainly, a place to play (MARQUES, 2011). They especially enjoyed play that involved broad movement, like running, pushing, and wrestling games. As in studies previously cited, they too indicated the need for appropriate spaces to carry out this type of play.

Even very small children show they are competent to discern how much they enjoy playing. One example of this is in the study conducted by Cruz and Cruz (2015) at a municipal institution in Fortaleza, where the participants, who were only three and four years old, revealed that they greatly valued the possibilities for play, in addition to the meals they received.

Despite the great attraction that individual electronic games exert over children, there are indications that the interaction with friends made possible by traditional play still provides special pleasure to children. The participants in the study by Ferreira (2014) at a public education institution in Palhoça, Santa Catarina, were between five and six and had access to these games, having the possibility of play experiences with digital technologies. However, they expressed

9 Though conducted in 2004-2005 (therefore, prior to the period encompassed here), it is important to register that in the Consultation on quality in early childhood education, a study of national scope, the children pointed unanimously to the presence of toys in a good state of conservation and the possibility of play as indispensable items for a good daycare or preschool (CAMPOS; CRUZ, 2006). 
that, nevertheless, they also sought traditional play and group interaction with their peers.

In the work by Tavares (2015), previously mentioned, the children also revealed that, at the institution, they like play, snack time, recess, painting, and learning to read. It is worth mentioning that, when thinking about children close to them - siblings, cousins, neighbors - that do not attend daycare because this service is not available in the community where they live, they realized that there are children who are disrespected concerning this right.

This centrality of play among the elements that make the educational context more pleasant ${ }^{10}$ has been recurrent in the research in which children opine on the services offered by daycares and preschools, as revealed in Cruz and Martins (2017). Children's perceptions of the importance and the role of play in their school experiences needs to be considered both in pedagogical proposals and daily teaching actions as well as in construction/reform policies of early childhood education institutions and the purchase of toys and materials used in play.

The children also spoke up about what, to them, makes a good teacher. Those heard by Farias (2013) in two classes from municipal preschools of Fortaleza emphasized that a good teacher “can't fight”, “doesn't put us in time out” and doesn't yell”, but rather "lets us play, drink water, use the bathroom, snack, and draw" and "tells stories". In addition to highlighting these positive characteristics, it was notable when they pinpointed, as well, that a good teacher "learns things to teach the kids" (p. 119), which reveals the competence they possessed to assess a relevant aspect of a good professional, that is, the need to invest in one's own formation. The children's speech also expressed the understanding that the early childhood educational space should be an environment of significant learning.

In this group, the girls especially, in addition to focusing on the state/ manner of being a good teacher ("happy", "nice”, caring, etc.), emphasized physical traits, like being pretty. It was curious to hear the speech of these and other children saying the teachers should also be well-dressed, "charming”, "dropdead gorgeous" and "painfully chic", which seems to indicate that the children appropriate the values of a society that praises physical appearance and power of consumption as an important personal trait.

It should be emphasized that, in this study (FARIAS, 2013), the children of the institution whose pedagogical proposal seemed more transmissive, centralized on the figure of the teacher, cited, recurrently, situations not compatible with a good teacher, such as punishments and prohibition of play or utilization of materials and space. Thus, in this group, there was greater emphasis on what a good teacher should not do.

The children also expressed themselves on the transition from early childhood education to elementary education. When reflecting on their 
expectations in relation to the first year of EE, five-year-olds from a municipal public school in the city of São Paulo emphasized "learning to read and write" and "learning math" as determinants for what grade they would attend (RABINOVICH, 2012). These same children elected play as the most pleasurable activity that could be had in the school context, something that, nevertheless, they did not expect to encounter in the subsequent year.

Similarly, children, also five-year-olds from a municipal public school in Fortaleza, recognized school as a legitimate space for growth, learning, and expansion of knowledge, and, at the same time, demonstrated a desire that school also be a space for play (LIMA, 2013). They perceived and lamented that play (permission or denial) was often used, in early childhood education, as a prize or a punishment, and imagined the absence of play would be even more intense in the first year of elementary school. As expressed in the words of one child: "Aunt, aunt, here [in the first grade room] it is just for studying, there aren't any toys!” (LIMA, 2013, p. 120).

Five- and six-year-olds attending preschool or the first year of elementary school at an institution in the countryside of Rio Grande do Sul also expressed this apprehension about non-satisfaction of their wish to play (FERNANDES, 2014). For the preschoolers, while "getting bigger" and learning to read and write seemed like the upside of going to elementary school, they feared there would be fewer opportunities for play, already scarce in the environment they attended, based on the preparation for the following stage of education. Another aspect of the transition between these stages of basic education was raised: they pointed out that the environments of these two contexts are similar in terms of spaces and opportunities of experiences.

The children were also heard with regard to ethnic-racial relations in the context of the early childhood education institutions. In one of these studies, children from Brazil, Colombia, and Peru expressed the values they appropriated throughout their life experiences, including about ethnic-racial relations ${ }^{11}$ (CRUZ, 2015a). These values tended to reinforce the discrimination of minority groups, especially people of color. However, it was perceived that negative conceptions about people of color were still in construction, being susceptible to change when offered opportunities to reflect on these discriminations. As reported by the author, "it was possible to perceive changes in positions based on conversations with classmates, mediated by the researchers: one child, for example, asked: 'Can I change my mind?'” (CRUZ, 2015a, p. 270).

As to the four-and five-year-olds from a municipal early childhood education institution in São José, Santa Catarina, they manifested many stereotypes and prejudices, such as pointing to physical aspects considered superior to others, exalting characteristics such as light skin color, straight hair, and slim bodies, which allowed for the establishment of a relation between corporeity and

11 The research sought to discover how different forms of discrimination manifested in institutions of early childhood education, but focused more specifically on gender, ethnic-racial discrimination, and against people with disabilities. 
ethnic-racial relations (GAUDIO, 2013). The girls commonly organized play and partner choices based on these esthetic standards. The research made it possible to reflect that the constitution of the identity of those children who are victims of discrimination, constructed historically, becomes conflictive, making it necessary to deconstruct representations that lower them and break the prejudices about their bodies.

Boys and girls from a preschool in the city of São Paulo also demonstrated negative conceptions about their own ethnic characteristics, which reverberate in the construction of the children's self-image (TRINIDAD, 2011). These children revealed familiarity with and employment of ethnic-racial categories in their play and interactions and, while not selecting their pairs based on skin color, expressed the desire to have characteristics associated with white people. This element indicates that the senses and meanings given to whites and blacks have already been appropriated. In relation to the children of inter-racial relationships, it was perceived that the more children presented physical traits that approached the black phenotype, the greater was the desire to be white.

Such observations on the presence of discrimination in the context of early childhood education and its effects on the process of children's construction of identity, as well as the small number of studies addressing this theme that listen directly to small children (between 19 months and three years, 11 months), motivated the work of Cruz (2015b), conducted in a municipal daycare of Fortaleza. The children appeared little sensitive to the ethnic-racial differences presented; almost none associated the discriminations narrated to ethnic-racial belonging or expressed it themselves, which led the author to raise the possibility that they had not had experiences in daycare in which the physical traits of blacks or that black people themselves had been affectively imbued with negative content. It is notable that, as in the previous study (CRUZ, 2015a), the children showed a great deal of empathy ${ }^{12}$ for the victims of discrimination, which was seen as an important element for avoiding complicity with it.

Children from an early childhood education class in a public institution in Recife heard by Silva (2015) added an important datum to the knowledge on this subject. In addition to the boys and girls demonstrating their competence in designating themselves racially, using terms closely approximating those commonly used in Brazil, they showed that they perceived themselves differently, according to their gender: while boys presented a discomfort because they were black, the girls showed pride and pleasure because of it. An intensification of pedagogical strategies centered on girls, especially valuing black feminine beauty, was identified by the author as a factor that may explain this variation.

Important reflections on this subject were also made possible by the expressions of young black children, only two and three years of age, heard

12 Schramm (2009) also identified empathy and solidarity in the children. In the case of her research, it was demonstrated in relation to a classmate subjected to an arbitrary rule of not being allowed to choose desk mates, when the children said she felt "bad" and "sad". 
by Santiago (2014) at a Childhood Education Center in a town in the greater Campinas-SP area. To the author, these children demonstrated resistance in the face of a "whiteness" pedagogy by means of different languages, such as crying, yelling, and biting, expressing their non-acceptance of the framework that put them in subordinate positions in situations experienced at the institution.

\section{FINAL CONSIDERATIONS}

Pedagogy conducts the encounter with children guided by the mission that it sets for itself and by means of "truths" that it has been constructing on its interpretation of the knowledge produced by various sciences. The customs, concerns (oftentimes unreasonable, like the need for the child to learn to read at a supposed "right age"), stereotypes, and even prejudices about children (especially poor children and children of color), which are hegemonic in society at each historical moment, are also brought to the school context and have made it difficult to hear the children. However, it is becoming more and more evident that listening to the children we work with is a necessity in order that early childhood education can know its subjects and improve its quality and, thus, accomplish its objective of promoting the welfare and learning and development of girls and boys that attend daycare or preschool classes.

The construction of quality pedagogical practices in childhood education requires, necessarily, respecting the rights of all children. One of these rights is to be heard and to have their opinion considered. In the daily routine of daycares and preschools, the interest in listening to children is very clear in pedagogical documentation, a practice that, according to Rinaldi (2014, p. 129, own translation), has as one of its most primary tasks to ensure listening and being listened to, through "traces/documents that testify to and make visible the ways of learning of individuals and the group". ${ }^{13}$

In the arena of research, knowing the perspective of children has expanded knowledge of their peculiarities, feelings, needs, and desires about the work developed in the institutions they attend. It has also furnished fundamental elements to the pedagogical practice, complementing the perceptions of school, in addition to contributing to the construction of a more positive image of children.

Many of the children's voices heard in the studies cited here, as already highlighted, denounce, oftentimes, violations of rights and demand rights that, indeed, have been affirmed in various studies about Childhood Pedagogy (ROCHA, 2000, 2013) and quality in early childhood education (ZABALZA, 1998; CAMPOS, 2010) and have already been guaranteed in official documents (BRASIL, 1995, 2006a, 2006b, 2009a, 2009b, 2009c). Nonetheless, what listening to the children reveals is that those rights are still not ensured in the daily life of many Brazilian Childhood Education institutions.

13 In the original: "traços/documentos que testemunhem e tornem visíveis os modos de aprendizado dos indivíduos e do grupo" 
The children's words also demonstrate what pleases them in the early childhood education institution, such as the fact that it is a place of learning. However, mostly, their speech indicates elements that would make them feel happier in these contexts of collective education, or in other words, ways that these environments could have better quality. They desire an environment in which the spaces are pleasant, that have many toys and where they can play when they want to. The teacher should be someone who promotes significant and engaging experiences and who does not act in a coercive or rude manner, “doesn't yell”. All of them, just as adults do, would like to be respected and valued in their diverse physical characteristics, skills, preferences, gender, religion, ethnic-racial belonging, etc., in order to construct a positive image of themselves. The children also reveal apprehensions and expectations about the transition from early childhood education to elementary education, especially regarding the possibility of expanding their learning and maintaining opportunities for interactions with friends and with play.

In order for research studies with children to continue to expand our knowledge on what they think and feel about subjects related to their educational experience, central questions continue to challenge researchers: How can we capture children's perspectives and experiences, developing methodologies appropriate to children's manner of expression and focusing on themes that are of their interest? How can we comprehend what they say, getting out of the adult-centric posture we commonly assume? How can we give visibility to their voices? How can we turn the greater knowledge of children's complaints, desires, apprehensions, curiosities, opinions in their favor?

The various answers to these and other questions will certainly make it possible to provide new information that will continue to arm social organisms and movements in defense of children's rights and subsidize public policies for childhood. Therefore, on several levels, they will add to other important contributions for the construction of quality in the education of babies, toddlers, and young children.

Finally, it is important to register how complex, difficult, and long the road to be taken still is in order that daycare and preschool can become, even partially, places that correspond to children's desires. In this way, the major problems, which range from the fragile formation of teachers (both initial and continued) to the underfinancing of this stage of education, will not be solved by listening to children, be it in research, or in the daily life of the institutions of Childhood Education. However, listening to them is fundamental for these institutions to become "a place of encounter and dialogue between citizens. A place of ethical and political praxis, a space for democratic learning" ${ }^{14}$ as Peter Moss (2009, p. 425, own translation) hopes. This transformation is fundamental 


\section{in order that the institution can be a welcoming and pleasant space, favoring pleasure, learning, and the enchantment of children.}

\section{REFERENCES}

ALMEIDA, S. do E. S. Participação de crianças nas rotinas da educação infantil. 2015. Dissertação (Mestrado em Educação) - Universidade Federal de Sergipe, Aracaju, 2015.

ANDRADE, R. C. A rotina da pré-escola na visão das professoras, das crianças e de suas famílias. 2007. Tese (Doutorado em Educação) - Universidade Federal do Ceará, Fortaleza, 2007.

BONDIOLI, A. (org.). 0 projeto pedagógico da creche e sua avaliação: a qualidade negociada. Campinas: Autores Associados, 2004.

BRASIL. Ministério da Educação. Secretaria da Educação Básica. Indicadores da qualidade na educação infantil. Brasília: MEC/SEB, 2009a.

BRASIL. Ministério da Educação. Secretaria de Educação Básica. Departamento de Política da Educação Fundamental. Coordenação de Educação Infantil. Critérios para um atendimento em creches que respeite os direitos fundamentais das crianças. Brasília: MEC/SEF/DPE/ COEDI, 2009b.

BRASIL. Ministério da Educação. Conselho Nacional de Educação. Câmara de Educação Básica. Resolução $n^{0} 5$, de 17/12/2009. Diretrizes Curriculares Nacionais para a educação infantil. Brasília, DF, 2009c.

BRASIL. Ministério da Educação. Secretaria de Educação Básica. Departamento de Política da Educação Fundamental. Coordenação de Educação Infantil. Parâmetros nacionais de qualidade para educação infantil. Brasília: MEC/SEB/DPE/COEDI, 2006a.

BRASIL. Ministério da Educação. Secretaria de Educação Básica. Departamento de Política da Educação Fundamental. Coordenação de Educação Infantil. Parâmetros básicos de infraestrutura para instituições de educação infantil. Brasília: MEC/SEB/DPE/COEDI, $2006 \mathrm{~b}$.

BRASIL. Ministério da Educação e Cultura. Coordenação de Educação Infantil. Critérios para um atendimento em creches que respeite os direitos fundamentais das crianças. Brasília: MEC/SEF/DPEF/COEDI, 1995.

CAMPAÑA LATINOAMERICANA POR EL DERECHO A LA EDUCACIÓN et al. Consulta sobre la discriminación en la educación en la primera infância: un estudio desde la perspectiva de la comunidad educativa en escuelas de Brasil, Perú y Colombia - Informe regional. São Paulo: Campaña Latinoamericana por el Derecho a la Educación, 2013.

CAMPOS, M. M. (coord.) Educação infantil no Brasil: avaliação qualitativa e quantitativa (Relatório Final). São Paulo: Fundação Carlos Chagas, 2010.

CAMPOS, M. M.; CRUZ, S. H. V. Consulta sobre Qualidade na Educação Infantil: o que pensam e querem os sujeitos desse direito. São Paulo: Cortez, 2006.

CAMPOS, M. M.; FÜLLGRAF, J.; WIGGERS, W. A qualidade da educação infantil brasileira: alguns resultados de pesquisa. Cadernos de Pesquisa, São Paulo, n. 127, p. 87-128, jan./abr. 2006.

CARVALHO, M. M. C. Quando a história da educação é a história da disciplina e da higienização das pessoas. In: FREITAS, M. C. (org.). História social da infância no Brasil. São Paulo: Cortez, 1997. p. 291-310

CAVALLEIRO, E. Do silêncio do lar ao silêncio escolar: racismo, preconceito e discriminação na educação infantil. 1998. Dissertação (Mestrado em Educação) - Universidade de São Paulo, São Paulo, 1998.

CHARLOT, B. A mistificação pedagógica: realidades sociais e processos ideológicos na teoria da educação. Rio de Janeiro: Zahar, 1983. 
CORSARO, W. A. Reprodução interpretativa e cultura de pares. In: MÜLLER, F.; CARVALHO, A. M. (org.).

Teoria e prática na pesquisa com crianças. São Paulo: Cortez, 2009. p. 31-50.

CORSARO, W. A reprodução interpretativa do brincar. Revista Educação, Sociedade e Cultura, Porto, n. 17, 2001.

CORSARO, W. A. Sociologia da infância. Porto Alegre: Artmed, 2011.

CORSI, B. R. Conflitos na Educação Infantil: o que as crianças têm a dizer sobre eles. Dissertação (Mestrado em Educação) - Universidade de São Paulo, São Paulo, 2010.

CRUZ, R. C. A. A pré-escola vista pelas crianças. In: REUNIÃO ANUAL DA ANPED, 32., Anais [...] Caxambu: ANPEd, 2009. p. 1-19.

CRUZ, S. H. V. Fala, menino! Uma experiência de pesquisa sobre o cotidiano da creche comunitária na perspectiva da criança. Educação em Debate (CESA/UFC), Fortaleza, v. 2, n. 44, p. 20-35, 2002.

CRUZ, S. H. V. A percepção sobre a discriminação étnico-racial entre crianças do Brasil, Colômbia e Peru. Revista Eletrônica de Educação, São Carlos, v. 9, p. 249-276, 2015.

CRUZ, S. H. V.; CRUZ, R. C.A. A perspectiva de crianças sobre a creche. Eventos Pedagógicos, v. 6, p. 155, 2015.

CRUZ, S. H. V.; MARTINS, C. A. Políticas públicas e a voz das crianças. Laplage em Revista, v. 3, p. 29-43, 2017.

CRUZ, S. H. V.; SANTOS, C. O. Perspectivas de crianças sobre o cotidiano da pré- escola: o recreio em foco. Textura, v. 18, p. 171-190, 2016.

DAHLBERG, G.; MOSS, P.; PENCE, A. Qualidade na educação da primeira infância: perspectivas pós-modernas. Porto Alegre: Artmed, 2003.

DIAS, L. R. No fio do horizonte: educadoras da primeira infância e o combate ao racismo. 2007. 2 v. Tese (Doutorado) - Universidade de São Paulo, São Paulo, 2007.

FARIAS, K. C. F. As concepções das crianças sobre as características de uma boa professora de educação infantil. Dissertação (Mestrado em Educação) - Universidade Federal do Ceará, Fortaleza, 2013.

FERNANDES, C. V. A identidade da pré-escola: entre a transição para o ensino fundamental e a obrigatoriedade de frequência. Tese (Doutorado em Educação) - Universidade Federal do Rio Grande do Sul, Porto Alegre, 2014.

FERREIRA, M. G. A cultura lúdica das crianças contemporâneas na sociedade multitela. Tese (Doutorado em Educação) - Universidade Federal de Santa Catarina, Florianópolis, 2014.

FOUCAULT, M. Vigiar e punir. Petrópolis: Vozes, 2005.

FREITAS, M. C. Da ideia de estudar a criança no pensamento social brasileiro: a contraface de um paradigma. In: FREITAS, M. C.; KUHLMANN JR., M. Os intelectuais e a história da infância. São Paulo: Cortez, 2002. p. $345-372$.

GAUDIO, E. S. Relações sociais na educação infantil: dimensões étnico-raciais, corporais e de gênero. 2013. Dissertação (Mestrado em Educação) - Universidade Federal de Santa Catarina, Florianópolis, 2013.

KORCZAK, J. Menosprezo e desconfiança. In: DALLARI, D. de A.; KORCZAK, J. 0 direito da criança ao respeito. São Paulo: Summus, 1986. p. 69-75. (Novas Buscas em Educação, v. 28).

KUHLMANN Jr., M. Infância e educação infantil: uma abordagem histórica. Porto Alegre: Mediação, 1998.

LIMA, I. M. M. As experiências educacionais no contexto da transição da educação infantil para o ensino fundamental numa escola municipal de Fortaleza na perspectiva dos diversos segmentos da comunidade escolar. 2013. Dissertação (Mestrado em Educação) - Universidade Federal do Ceará, Fortaleza, 2013. 
MARQUES, F. M. Concepções de crianças sobre escola de educação infantil. 2011. Dissertação (Mestrado em Educação) - Universidade Federal do Rio Grande do Sul, Porto Alegre, 2011.

MARTINS, C. A. A participação de crianças e professora na constituição da brincadeira na educação infantil. 2009. Tese (Doutorado em Educação) - Universidade Federal do Ceará, Fortaleza, 2009.

MOSS, P. Introduzindo a política na creche: a educação infantil como prática democrática. Psicologia USP, São Paulo, v. 20, n. 3, p. 417-436, jul./set. 2009.

OLIVEIRA, F. de. Um estudo sobre a creche: o que as práticas pedagógicas produzem e revelam sobre a questão racial? 2004. Dissertação (Mestrado) - Universidade Federal de São Carlos, São Carlos, 2004.

OLIVEIRA-FORMOSINHO, J. A visão de qualidade da Associação Criança: contributos para uma definição. In OLIVEIRA-FORMOSINHO, Júlia \& FORMOSINHO, João. Associação Criança: um contexto de educação em contexto. Coleção Mundo universitário. Braga -Portugal: Livraria Minho, 2001. p. 166-176.

OLIVEIRA-FORMOSINHO, J.; FORMOSINHO, J. A perspectiva pedagógica da Associação Criança: a Pedagogiaem-Participação. In: OLIVEIRA-FORMOSINHO, J.; GAMBOA, R. (org.). 0 trabalho de projeto na Pedagogia-emParticipação. Porto: Porto, 201, p. 11-45.

OLIVEIRA-FORMOSINHO, J.; FORMOSINHO, J. A perspectiva educativa da associação criança: a Pedagogiaem-Participação. In: OLIVEIRA-FORMOSINHO, J. (org.). Modelos curriculares para a educação de infância: construindo uma prática de participação. Porto: Porto, 2013, p. 25-60.

PAMPHYLIO, M. M. Os dizeres das crianças da Amazônia amapaense sobre infância e escola. 2010. Dissertação (Mestrado em Educação) - Universidade do Estado do Pará, Belém, 2010.

RABINOVICH, S. B. A articulação da educação infantil com o ensino fundamental I: a voz das crianças, dos professores e da família em relação ao ingresso no $1^{\circ}$ ano. 2012. Tese (Doutorado em Educação) Universidade de São Paulo, São Paulo, 2012.

ROCHA, E. A. C. A Pedagogia e a educação infantil. Revista Iberoamericana de Educación, Madri, v. 1, n. 22, p. 61-74, 2000.

ROCHA, E. A. C. Educação infantil: trajetórias de pesquisa e implicações pedagógicas. In: ROCHA, E. A. C. R.; KRAMER, S. (org.). Educação infantil: enfoques em diálogo. 3. ed. São Paulo: Papirus, 2013. v. 1, p. 367-384.

ROSEMBERG, F. Educação infantil, classe, raça e gênero. Cadernos de Pesquisa, São Paulo, n. 96, p. 58-65, fev. 1996.

ROUSSEAU, J.-J. Emilio, ou da educação. São Paulo: Martins Fontes, 1999.

SANTIAGO, F. "O meu cabelo é assim... igualzinho o da bruxa, todo armado": hierarquização e racialização das crianças pequenininhas negras na educação infantil. 2014. Dissertação (Mestrado em Educação) Universidade Estadual de Campinas, Campinas, São Paulo, 2014.

SANTOS, C. O. dos. As concepções das crianças, professora e coordenadora pedagógica sobre o recreio como atividade da rotina em uma escola pública de educação infantil na cidade de Fortaleza. 2015. Dissertação (Mestrado em Educação) - Universidade Federal do Ceará, Fortaleza, 2015.

SARMENTO, M. J. Sociologia da infância: correntes e confluências. In: SARMENTO, M.; GOUVEA, M. C. S. de. (org.). Estudos da infância: educação e práticas sociais. Petrópolis: Vozes, 2008. p. 17-39.

SCHRAMM, S. M. O. A construção do eu no contexto da educação infantil: influências da escola e a perspectiva da criança sobre esse processo. 2009. Tese (Doutorado em Educação) - Universidade Federal do Ceará, Fortaleza, 2009.

SILVA, V. L. N. da. Os estereótipos racistas nas falas de educadoras infantis: suas implicações no cotidiano escolar da criança negra. 2002. Dissertação (Mestrado em Educação) - Universidade Federal Fluminense, Rio de Janeiro, 2002. 
SILVA, T. R. da. Criança e negra: o direito à afirmação da identidade negra na educação infantil. 2015. Tese (Doutorado em Educação) - Universidade Federal da Paraíba, João Pessoa, 2015.

TAVARES, L. H. de J. Educação infantil e direito: o que dizem as crianças? 2015. Dissertação (Mestrado em Educação) - Universidade Federal do Estado do Rio de Janeiro, Rio de Janeiro, 2015.

TRINIDAD, C. T. Identificação étnico-racial em espaços de educação infantil. 2011. Tese (Doutorado) - Pontifícia Universidade Católica de São Paulo, São Paulo, 2011.

WARDE, M. Para uma história disciplinar: psicologia, criança e pedagogia. In: FREITAS, M. C. (org.). História social da infância no Brasil. São Paulo: Cortez, 1997. p. 311-332.

ZABALZA, M. Qualidade em educação infantil. Porto Alegre: Artmed, 1998.

NOTE: The authors contributed equally in the preparation and revision of the article.

HOW TO CITE THIS ARTICLE

CRUZ, Silvia Helena Vieira; SCHRAMM, Sandra Maria de Oliveira. Listening to the children in research and quality of early childhood education. Cadernos de Pesquisa, São Paulo, v. 49, n. 174, p. 16-35, Oct./Dec. 2019. https://doi.org/10.1590/198053146035 